\title{
An overview of organic agriculture: A potential strategy for climate change mitigation
}

\author{
G. T. Patle*, K. K. Badyopadhyay ${ }^{1}$ and Mukesh Kumar ${ }^{2}$ \\ Department of Soil and Water Engineering, College of Agricultural Engineering and Post Harvest Technology, \\ Gangtok -737135, INDIA \\ ${ }^{1}$ Division of Agricultural Physics, Indian Agricultural Research Institute, New Delhi - 110012, INDIA \\ ${ }^{2}$ Water Technology Centre, Indian Agricultural Research Institute, New Delhi - 110012, INDIA \\ *Corresponding author. E-mail: gtpatle77@gmail.com
}

Received: May 23, 2014; Revised received: August 18, 2014 ; Accepted: October 18, 2014

\begin{abstract}
Indian agriculture has changed considerably in the past several decades. Since post green revolution era, Indian farming basically shifted from the conventional farming system to towards the mechanized farming system and relies heavily on agricultural inputs such as chemical fertilizers, pesticides, heavy farm machineries and irrigation, which are dependent on fossil fuels. Large scale use of these inputs also contributed in emission of greenhouse gases which are mainly responsible for global warming and consequently climate change. Agriculture plays a unique role in the climate change mitigation because of its potential to lower greenhouse gases emissions through carbon sequestration. Organic agriculture is being considered as one of the appropriate farming systems that could serve the twin objectives of climate change mitigation and adaptation. Compared to conventional agriculture, organic agriculture is considered to be more energy efficient and effective both in reducing green house gases emission mainly due to the less use of chemical fertilizers and fossil fuel and enhancing the soil organic carbon. Promotion and adaptation of organic farming in developing country like India can serve as mitigation strategy of climate change.
\end{abstract}

Keywords: Climate change, GHG, INCCA, Mitigation, Organic agriculture

\section{INTRODUCTION}

Global agricultural food production system is principally climate driven. Climate change, its impacts and vulnerabilities on agriculture and associated sector is a matter of big concern in the current era (Goyal, 2004; Kumar et al., 2004; Mimi and Jamous, 2010; Verge et al., 2007; Wani et al., 2013). Although climate change is a natural phenomenon but worldwide studies on climate change and its consequences have put the evidences of unfavorable effect of climate change on agriculture and allied sectors (Garg et al., 2001; Kumar and Parikh, 2001; Aggarwal, 2003; Mall et al., 2006; Patle et al., 2013a). It is reported that agriculture contributes about $13.5 \%$ to $30 \%$ of all global emissions of greenhouse gases (Foereid et al., 2008). It is now accepted that anthropogenic activities are responsible for increased concentration of greenhouse gases (GHGs) in the atmosphere and is the major causes of global warming (IPCC, 2001). Intergovernmental panel on climate change (IPCC) clearly reported that global mean surface air temperature would increase by 1.1 to $6.4{ }^{\circ} \mathrm{C}$ by 2100 under different emission scenarios (IPCC, 2007a). Similarly, Indian network on climate change assessment has also reported an all-round warming $\left(1.7^{\circ} \mathrm{C}\right.$ to $\left.2.0^{\circ} \mathrm{C}\right)$ and increase in rainfall (3\% to $7 \%$ ) over the Indian subcontinent by the 2030s (INCCA, 2010). Krishna Kumar et al. (2011) also projected to rise in mean air temperature and rainfall by 2080s in the India. In developing countries like India, climate change and its probable impact on agriculture pay a special attention because agriculture play a vital role in the country's economy. Agriculture accounts for the $14 \%$ of the nation's GDP and $11 \%$ of its exports and about half of the population still relies on agriculture as its principal source of income. Similarly, agriculture is a source of raw material for a large number of industries (MOA, 2012).

Climate change may affect adversely the crop production system, water availability and can induce the food security problems for millions of peoples in the future (Sinha et al., 1998). In India, agriculture contributes about $17.6 \%$ of the country's total GHGs emission (INCCA, 2010). An intensive agricultural practice during the post green revolution era without caring for the environment has supposedly played a major role towards enhancement of the greenhouse gases. Due to increase in demand for food production the farmers have started growing more than one crop a year through repeated tillage operations using conventional agricultural practices (Patle et al., 2013b). Since post green revolution era, Indian farming basically shifted from the conventional agricultural practices to towards ISSN : 0974-9411 (Print), 2231-5209 (Online) All Rights Reserved @ Applied and Natural Science Foundation www.ansfoundation.org 
the mechanized practices and depend greatly on agricultural input such as chemical fertilizers, pesticides, irrigation and heavy farm machineries which are mainly dependent on fossil fuels (West and Marland, 2002, Lal, 2004a, Patle et al., 2013b). Heavy use of agricultural input and the mechanized farming helps a lot to increase the food grain production (Aggarwal et al., 2004; Mall et al., 2006). During the period, food grain production increased from 50 million tonnes in 1950-51 to 259.32 million tonnes during 2011-12 (MOA, 2012). But the large scale use of these inputs also contributed in the emission of green house gases directly or indirectly responsible for global warming and consequently climate change (Lal, 2004a).

Basically agriculture plays a double role as a source and sinks for the green house gases (Aggarwal, 2003; Lal, 2004b; Gattinger et al., 2012). To date, the agricultural sector has been largely overlooked as both a source of GHG emissions and a potential tool for mitigation (Lal, 2004a). Agricultural systems contribute to carbon emissions through the direct use of fossil fuels in farm operations, indirect use of embodied energy in inputs that are energy-intensive to manufacture (particularly fertilizers) and the cultivation of soils resulting in loss of soil organic matter. On the other hand, agriculture builds up carbon in the form of organic matter in the soil or above-ground in the form of biomass (Pretty and Ball, 2001). However, agriculture has a unique role to play in climate change mitigation because of its potential to lower GHG emissions through carbon sequestration. Organic agriculture proved its potential to reduce the GHG emissions through carbon sequestration and use of less input (Gattinger et al., 2012). Therefore in the context of climate change, conversion from conventional agriculture to organic agriculture is being considered as one of the appropriate farming system that could serve the twin objectives of climate change mitigation and environment protection (Lal, 2004a; FAO, 2011). Promotion and adaptation of organic farming in developing country like India can be one of the effective mitigation strategies of climate change. Based on the available information, this paper focuses on the present status and future potential of organic farming in India for climate change mitigation.

\section{GHGS EMISSION FROM GLOBAL AGRICULTURE}

In general, agriculture sector contribute to the emission of three major greenhouse gases viz., carbon di oxide $\left(\mathrm{CO}_{2}\right)$, methane $\left(\mathrm{CH}_{4}\right)$ and nitrous oxide $\left(\mathrm{N}_{2} \mathrm{O}\right)$ (West and Marland, 2002). The global atmospheric concentration of carbon di-oxide, methane and nitrous oxide increased from a pre-industrial value of about $280 \mathrm{ppm}$ to $379 \mathrm{ppm}, 715 \mathrm{ppb}$ to $1732 \mathrm{ppb}$ and 270 ppb to 319 ppb in 2005 (IPCC, 2007a). Reason behind the global increase in $\mathrm{CO}_{2}$ concentrations are mainly due to use of fossil fuel and land use change, $\mathrm{CH}_{4}$ concentration is predominantly due to agriculture and fossil fuel use and $\mathrm{N}_{2} \mathrm{O}$ concentration is primarily due to agriculture (Lal, 2004a, ). According to IPCC, in 2005 , agriculture accounted for $10-12 \%$ of total global anthropogenic emissions of greenhouse gases in the atmosphere. The annual amount of greenhouse gases emitted by the agricultural sector is estimated at between 5.1 and 6.1 giga-tonnes $\mathrm{CO}_{2}$ equivalents in 2005 (IPCC, 2007a). Of these emissions, methane accounts for 3.3 giga-tonnes equivalents and nitrous oxide for 2.8 giga-tonnes $\mathrm{CO}_{2}$ equivalents annually while net emissions of $\mathrm{CO}_{2}$ was only 0.04 giga-tonnes $\mathrm{CO}_{2}$ equivalents per year. From this, it was observed that agriculture is the main emitter of nitrous oxides and methane according to current practice and knowledge. $\mathrm{N}_{2} \mathrm{O}$ emissions from soils and $\mathrm{CH}_{4}$ from enteric fermentation constitute the largest sources, $38 \%$ and $32 \%$ of total non- $\mathrm{CO}_{2}$ emissions from agriculture in 2005, respectively. Biomass burning $(12 \%)$, rice production $(11 \%)$, and manure management (7\%) account for the rest. When considering the total food chain from the farm to the consumer, emissions from all the other sectors need to be included. Thus, the greenhouse gas emissions from all sectors related to agriculture may potentially sum up to $25-30 \%$ of all GHG emissions.

\section{GHGS EMISSION FROM INDIAN AGRICULTURE}

India accounts for only about $2.4 \%$ of the world's geographical area; supports about $17 \%$ of the world's human population and $15 \%$ of the livestock. Agriculture is the mainstay of $60 \%$ of its population (MOA, 2012). An agriculture sector contributed about $17.6 \%$ of total country's GHG emissions in 2007 and this figure is expected to increase further (INCCA, 2010). India is mostly blamed for higher GHGs emission due to having large number of livestock and more area under paddy cultivation (INCCA, 2010). In the year 2007, Indian agriculture sector emitted 334.41 million tonnes of $\mathrm{CO}_{2}$ equivalent, of which 13.7 million tonnes was methane and 0.15 million tones was nitrous oxide. Enteric fermentation constituted $63 \%$ of the total $\mathrm{CO}_{2}$ equivalent emissions from this sector, $21 \%$ of the emissions were from the rice cultivation. Crop soils emitted $13 \%$ of the total $\mathrm{CO}_{2}$ equivalent emission from the agriculture. Remaining $2.7 \%$ of the emissions were attributed to livestock manure management and burning of crop residue (Fig. 1). Greenhouse gases attributed to agriculture by the IPCC and INCCA include emissions from soils, enteric fermentation, rice production, biomass burning and manure management. This does not include the emissions from other indirect sources under agriculture such as GHG emissions from land-use changes, use of fossil fuels for mechanization, transport and agro-chemical and fertilizer production. Table 1 shows the green house gases produced from agriculture sector under different emission categories. 
Table 1. Greenhouse gases from agriculture sector under different emission categories.

\begin{tabular}{lll}
\hline Sector & Emission category & $\begin{array}{l}\text { Gases } \\
\text { produced }\end{array}$ \\
\hline Agriculture & Enteric fermentation in & $\mathrm{CO}_{2}, \mathrm{CH}_{4}$, \\
& livestock, manure management & $\mathrm{N}_{2} \mathrm{O}$ \\
& Rice cultivation & $\mathrm{CH}_{4}$ \\
& Agricultural soils & $\mathrm{N}_{2} \mathrm{O}$ \\
& Burning of crop residue & $\mathrm{CH}_{4}, \mathrm{~N}_{2} \mathrm{O}$ \\
\hline
\end{tabular}

(Source: IPCC, 2001; Patle et al., 2013b)

Table 2. Growth of area under organic development in India.

\begin{tabular}{lcc}
\hline Years & \multicolumn{2}{c}{ Area in ha under organic certification process } \\
\cline { 2 - 3 } & $\begin{array}{c}\text { Cultivated } \\
\text { (Organic + in-conversion) }\end{array}$ & Wild harvest \\
\hline $2003-04$ & 42000 & NA \\
$2004-05$ & 76000 & NA \\
$2005-06$ & 1,73000 & NA \\
$2006-07$ & 5,38000 & $24,32,500$ \\
$2007-08$ & 8,65000 & $24,32,500$ \\
$2008-09$ & $12,07,000$ & $30,55,000$ \\
$2009-10$ & $10,85,648$ & $33,96,000$ \\
$2010-11$ & $7,77,517$ & $36,50,000$ \\
\hline
\end{tabular}

NA- Not available (Source: Yadav, 2012)

\section{PROJECTED IMPACT OF CLIMATE CHANGE ON AGRICULTURE}

As per Intergovernmental panel on climate change assessment, crop productivity is projected to increase slightly at mid to high latitudes for local mean temperature increases of up to 1 to $3^{\circ} \mathrm{C}$ depending on the crop, and then decrease beyond that in some regions. At lower latitudes, especially in seasonally dry and tropical regions, crop productivity is projected to decrease for even small local temperature increases ( 1 to $2{ }^{\circ} \mathrm{C}$ ), which would increase the risk of hunger (IPCC, 2007a). Increases in the frequency and severity of floods and droughts are projected to adversely affect sustainable agriculture development (IPCC, 2007b).

According to the climate change projections of INCCA, the mean temperature in India would increase by $0.1-0.3^{\circ} \mathrm{C}$ in kharif and $0.3-0.7^{\circ} \mathrm{C}$ during rabi season by 2010 and by $0.4-2.0^{\circ} \mathrm{C}$ during kharif and to $1.1-4.5^{\circ} \mathrm{C}$ in rabi by 2070 . Mean rainfall would not change by 2010 and would increase by upto $10 \%$ during kharif and rabi by 2070. INCCA further reported that there is an increased possibility of climate extremes, such as the timing of onset of monsoon, intensities and frequencies of drought and floods (Khan et al., 2009). Different studies reported decrease in the grain yield due to increase in temperature in India (Rao and Sinha, 1994; Mall et al., 2006). Sinha and Swaminathan (1991) reported that a $2^{\circ} \mathrm{C}$ increase in mean air temperature would decrease rice yield by about $0.75 \mathrm{t} / \mathrm{ha}$ in the high yield areas and by about $0.06 \mathrm{t} / \mathrm{ha}$ in the low yield coastal regions. Further, a $0.5^{\circ} \mathrm{C}$ increase in winter temperature would reduce wheat crop duration by seven days and reduce yield by 0.45 ton per hectare. Aggarawal and Sinha (1993) showed that in North India, a $1^{\circ} \mathrm{C}$ rise in mean temperature would have no significant effect on wheat yields, while a $2^{\circ} \mathrm{C}$ increase would reduce yields in most places.

\section{CLIMATE CHANGE MITIGATION STRATEGIES FOR AGRICULTURE SECTOR}

Intergovernmental panel on climate change (IPCC, 2007b) has suggested following mitigation technologies and practices which currently commercially available and useful for the mitigation of climate change impacts on agriculture sector before 2030s (i.e. average of period 2021-2050).

Restoration of cultivated peaty soils and degraded lands.

Improved crop and grazing land management to increase soil carbon storage.

Improved rice cultivation techniques and livestock and manure management to reduce methane emission.

Improved nitrogen fertilizer application techniques to reduce nitrous oxide emissions.

Dedicated energy crops to replace fossil fuel use.

Improved energy efficiency and improvement of crop yields.

In addition to above IPCC also suggested some of the adaptation strategies for agriculture sector like adjustment of planting dates and crop variety, crop relocation, improved land management e.g. erosion control and soil protection through tree planting, use of rainwater harvesting, water storage and conservation techniques, water-use and irrigation efficiency. Above all strategies are site and location specific and can be used as per applicability.

\section{ORGANIC AGRICULTURE WHY?}

Sustainable agriculture to meet the country's food production requires sustainability of the natural resources. Natural resources which play an important role in the crop production system include viz. arable land, water, soil and biodiversity. These natural resources are rapidly shrinking due to pressures of increasing population density, socio-economic pressures, impact of climatic variability on monsoon (temporal and spatial variation in rainfall), increase in surface temperature and increasing phenomenon likes floods and droughts (Chakraborty, 1998; Sharma, 2001). Other problem includes rapidly decline of groundwater levels in the several parts of the country (CGWB, 2009), deteriorating soil health due to over use, soil erosion and imbalanced use of fertilizers (Pandey and Singh, 2012). Depleting water resources and the land degradation are major threat to country's food production and environmental security. Therefore, proper management of natural resources is needed. Organic agriculture can serve the purpose to ensure sustainable agriculture due to its holistic approach of 
Table 3. Criteria of labeling for organic product according to the year of production.

\begin{tabular}{llccc}
\hline Crops & \multicolumn{4}{c}{ Year wise label } \\
\cline { 2 - 5 } & First year & Second year & Third year & Fourth year \\
\hline Annual & No label & In conversion to organic Agriculture & Certified organic & Certified organic \\
Perennial & No label & In conversion to organic Agriculture & In conversion to organic Agriculture & Certified organic \\
\hline
\end{tabular}

(Source: Maity and Tripathi, 2004)

organic crop production system and have potential for meeting food demand, maintaining soil fertility and increasing soil carbon pool in context of climate change (Pandey and Singh, 2012). Basically an organic production system is designed to-

Enhance biological diversity within the whole system Increase soil biological activity.

Maintain long-term soil fertility.

Recycle wastes of plant and animal origin in order to return nutrients to the land, thus minimizing the use of non-renewable resources.

Rely on renewable resources in locally organized agricultural systems.

Promote the healthy use of soil, water, and air, as well as minimize all forms of pollution thereto that may result from agricultural practices (Source: Muller, 2009).

\section{ORGANIC AGRICULTURE AND MITIGATION OF CLIMATE CHANGE}

Organic agriculture is defined as the production system that sustains the health of soils, ecosystems and people (IFOAM, 2006). In principle, organic farming basically depend upon the crop rotations, crop residues, animal manures, farm organic waste, mineral grade rock additives and biological system of nutrient management and pest and disease control. It avoids the use of chemical fertilizers, pesticides, hormones, feed additives etc. Therefore, organic agriculture is looked as one of the solutions for climate change mitigation because it emits much lower levels of greenhouse gases (GHG), and also effectively sequesters carbon in the soil (Panwar et al., 2010; IFOAM, 2009). In addition to this organic agriculture also makes farms and people more resilient to climate change, mainly due to its water efficiency, resilience to extreme weather events and lower risk of complete crop failure.

It is believed that shifting from conventional crop production systems to organic crop production systems would significantly lower the emission of greenhouse gases because organic production systems produce smaller amount GHG emissions than conventional industrial farming systems (Meredith, 2008; Mullar, 2009; Pandey and Singh, 2012). Global adoption of organic agriculture has the potential to sequester up to the equivalent of $32 \%$ of all current man-made GHG emissions (Jordan et al., 2009). FAO also stated that organic systems contribute less to GHG emissions due to use of lower energy inputs and sequesters more carbon in the biomass than conventional systems
(Ziesemer, 2007). Eyhorn et al. (2007) reported that organic farming is a low-risk farming strategy with reduced input costs, therefore, lower risks with partial or total crop failure due to extreme weather events or changed conditions in the wake of climate change and variability. Aher et al. (2012) reported that organic yields match with the conventional yields and organic farming uses $45 \%$ less energy and is more efficient than the conventional farming systems.

\section{GLOBAL STATUS OF ORGANIC AGRICULTURE}

Globally total area under organic agriculture constitutes 80 million hectares. Out of which 37 million hectares represent organic agricultural land including in conversion areas which shares $0.9 \%$ of the world's total agricultural land. Non agricultural organic area constitutes 43 million ha (i.e. area under wild collection, aquaculture, forests and grazing areas). Area under the organic agriculture increased from 11 million hectares in 1999 to 37 million hectares in 2010 (IFOAM, 2012). Globally, Oceania shares the highest area of organic land (12.1 mha) followed by the Europe (10 mha), Latin America (8.4 million ha), Asia (7.5\%), Northern America $(7.2 \%)$ and Africa having $2.9 \%$ area under organic agriculture (Fig. 2). Country wise area under organic agricultural land is highest in Australia (12.0 mha), followed by the Argentina (4.18 mha), United states (1.95 mha), Brazil (1.77 mha), Spain (1.46 mha), China (1.39 mha), Italy (1.11 mha), Germany (0.99 mha) and India consists 0.78 million hectares (IFOAM, 2012). According to the IFOAM (2012) statistics, there are 1.6 millions of organic producers and among which $34 \%$ are in Africa followed by Asia (29\%) and 18\% in Europe. Among the countries, India have largest producer of organic commodities $(4,00,551$ millions) followed by the Uganda (1,88,625millions) and Mexico (1,28,862 millions). In 2010, the global sales of organic food and drink reached to 59 billion US dollar which was 3 fold more as in the year 2000 .

\section{STATUS OF ORGANIC AGRICULTURE IN INDIA}

India having the total geographical area of 328.73 million hectares consists 142.02 million ha net sown area and 63.26 million hectares net irrigated area. Organic farming is a state of art in India and is being followed by the farmers from the ancient times and the crop production system was mostly organically 


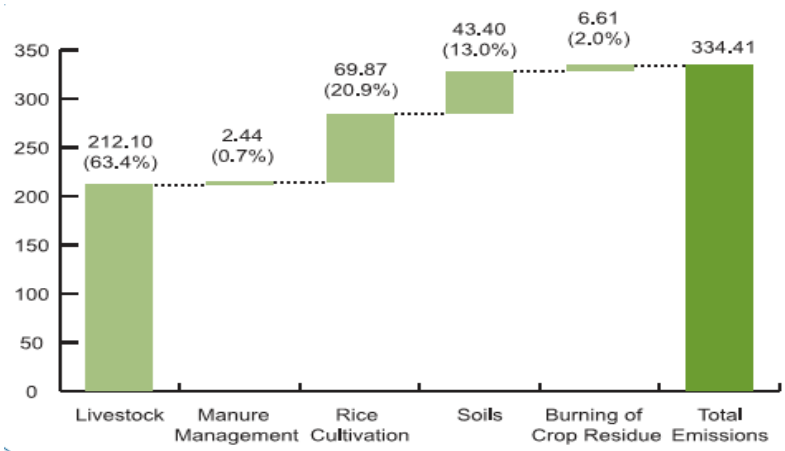

Fig. 1. $\mathrm{CO}_{2}$ equivalent emissions from agriculture sector in million tons. (Source: INCCA, 2010).

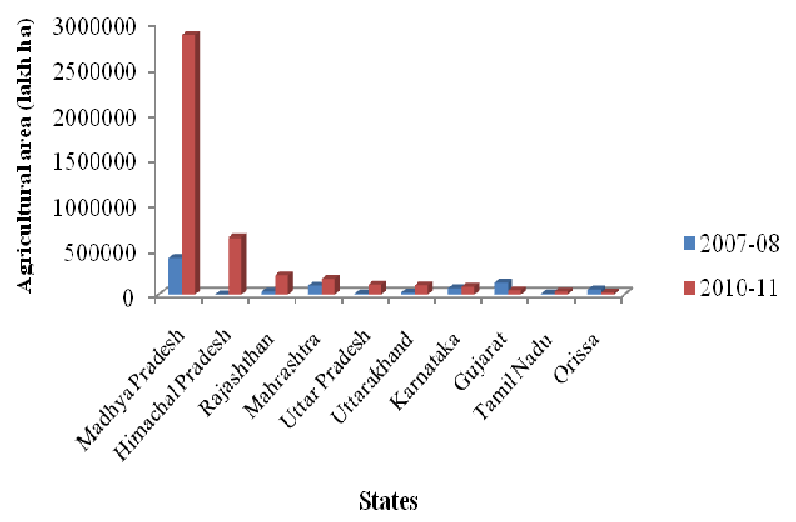

Fig. 3. State wise agricultural area under organic farming (Source: www.indiastat.com).

managed till the introduction of chemical fertilizers and pesticides in Indian agriculture (Pandey and Singh, 2012; Wani et al., 2013) It is also known by the various names viz., Vedic krishi, biodynamic farming, nature farming, eco-farming, traditional organic farming and homa farming etc.

In India only $30 \%$ of total cultivable area is covered with fertilizers where irrigation facilities are available and in the remaining $70 \%$ of arable land, which is mainly rain-fed, negligible amount of fertilizers is being used and mostly managed by farm yard manures or compost (Maity and Tripathi, 2004). Area under organic farming in India increased from 42,000 hectares in 2003-04 to more than 4.43 million ha in 2010-11 (Table 2). The cultivated area under organic farming accounts to 0.77 million ha while remaining 3.65 million ha was wild forest area (Yadav, 2012).

Among the states, Madhya Pradesh comprise largest area under organic farming followed by Himachal Pradesh, Rajasthan, Maharashtra, Uttar Pradesh, Uttarakhand, Karnataka, Gujarat, Tamil Nadu and Orissa. The area under all most all states increased from 2007-08 to 2010-11 except in the state of Gujarat. But area under organic farming increased several fold in the state of Madhya Pradesh as compared to other states of the country (Fig. 3).

In case of north east states of India, Mizoram consist of the highest area under organic farming (38674.62 ha), followed by the Nagaland (29715.28 ha), Manipur

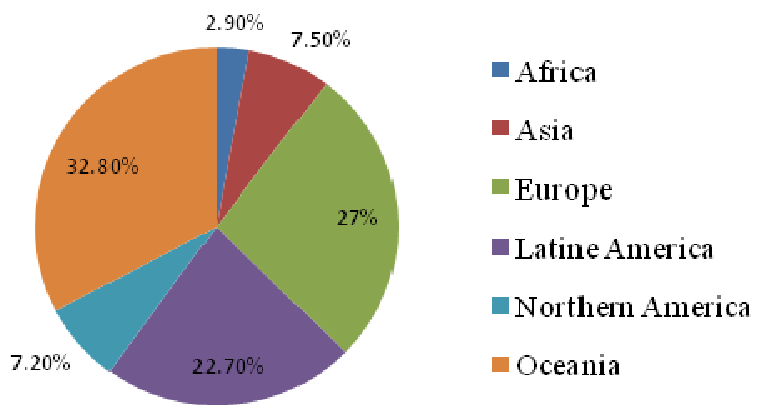

Fig. 2. Distribution of organic agricultural land in the world. Source: IFOAM, 2012)

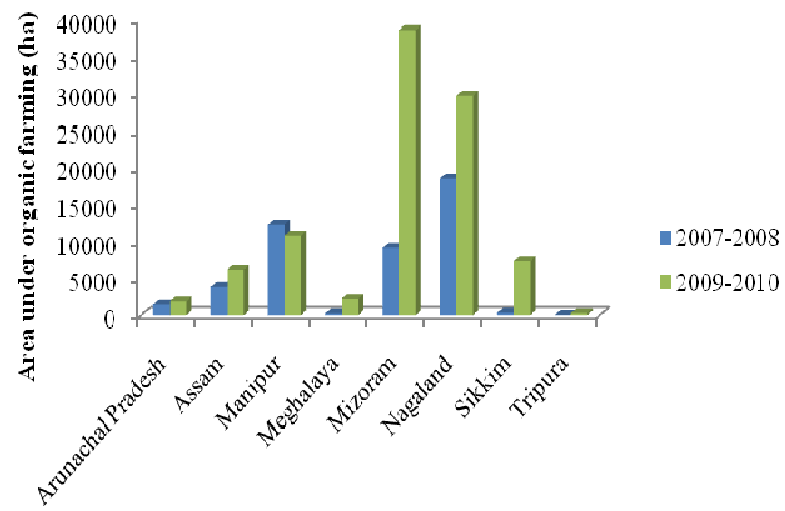

Fig. 4. Area under organic agriculture in north-east states of India (Source: www.indiastat.com).

(10871.3 ha), Sikkim (7393.09 ha), Assam (6223.12 ha), Meghalaya (2254.12 ha), Arunachal Pradesh (1897.27 ha) and 281.06 ha in Tripura (Fig. 4). The north east region of India is blessed with rich biodiversity, rich soil organic carbon and has low fertilizer consumption. These are the major strength for large scale adoption of organic farming. Yadav (2012) reported that about 18 million hectares of land is available in the north east (NE), which can be exploited for organic production.

Among crops cotton is the single largest crop accounting for nearly 40 percent of total organic area followed by rice, pulses, oilseeds and spices. India is the largest organic cotton grower in world, and accounts for $50 \%$ share of total world organic cotton production (Bhattacharyya and Chakraborty, 2005). India has great potential to grow crops organically and have emerged as a major supplier of organic products in the world's organic market.

\section{PROMOTION OF ORGANIC FARMING IN INDIA}

India is endowed with various types of naturally available organic form of nutrients in different parts of the country and it would help for organic cultivation of crops substantially. Organic farms although yield on an average $10-15 \%$ less than conventional farms, the lower yields are balanced by lower input costs and higher margins (Pandey and Singh, 2012). Organic 
farming is being promoted under national project on organic farming, national horticulture mission and rashtriya krishi vikas yojana.

States like Uttarakhand, Nagaland, Sikkim and Mizoram have declared their intention to go $100 \%$ organic. Sikkim has already converted nearly 40 percent of its total cultivated area under organic and has set target to convert entire state to organic by 2015 . At present, following six authorized accreditation agencies are working in India.

APEDA (Agricultural and Processed Food Product Export Development Authority)

Coffee Board

Spices Board

Tea Board

Coconut Development Board

Cocoa and Cashew nut Board

At country level, Indian organic certification agency (INDOCERT) is a local organic certification body which was established in March, 2002. The major objectives of INDOCERT is to offer a reliable and affordable organic inspection and certification services to farmers, processors, input suppliers and traders (Maity and Tripathi, 2004). Table 3 show the criteria for labeling of organic product according to the year of production as follows

\section{POTENTIAL OF ORGANIC AGRICULTURE FOR CLIMATE CHANGE MITIGATION}

Potential of organic agriculture for climate change mitigation is based on its capacity of carbon sequestration, reduction in the energy use and lowering the greenhouse gases emission.

Enhancing carbon sequestration: Soils are the major sink for atmospheric $\mathrm{CO}_{2}$. Organic farming increases organic carbon through organic manures, crop cover and crop rotation and restores it for the longer duration. It is reported that soil carbon sequestration rates on arable land can range from $200 \mathrm{~kg}$ to $2000 \mathrm{~kg}$ of carbon per hectare per year above 'business as usual' conventional agriculture depending on the organic agriculture soil management practice (IFOAM, 2009). Global adoption of organic agriculture has the potential to sequester up to the equivalent of $32 \%$ of all current man-made GHG emissions (Jorden et al., 2009).

Reduction in energy use in agriculture: Organic agriculture reduces the direct and indirect use of energy in agriculture. It is reported that organic farming systems use 20 to $50 \%$ less energy compared to the conventional farming system (Pimentel et al., 2005; Schader et al., 2011 and Muller et al., 2012). In the USA, high-input industrialized systems consumed $22-120 \%$ more energy than sustainable and organic systems and achieved similar yields (Pretty and Ball, 2001). Lampkin (2007) reported that the lower energy use on organic farms is largely because industrial fertilizers and pesticides are not used, thus avoiding the energy inputs for their production. Pimentel et al.
(2005) reported that organic no-till practice saved $61 \%$ of fuel/ha compared to conventional no-till corn production practice and organic tillage farming practice saved $47 \%$ fuel per hectare as compared to the conventional tillage practice. Pretty and Ball (2001) compared sustainable and low-input systems of production with the high-input conventional systems for both developed and developing countries and reported that low-input or organic rice in Bangladesh, China, and Latin America was 15-25 times more energy efficient than irrigated rice produced in the USA. They further reported that for each tonne of cereal or vegetable production from the modernized high-input systems consumed 3000-10,000 MJ of energy compared to the 500-1000 MJ for sustainable farming.

Lower greenhouse gas emissions: Olesen et al. (2006) reported that organic agriculture emits lower $\mathrm{N}_{2} \mathrm{O}$ from nitrogen application, due to lower overall nitrogen input per ha than in conventional agriculture. Greenhouse gas emissions were calculated to be 48-66 percent lower per hectare in organic farming systems in Europe and were attributed to no input of chemical $\mathrm{N}$ fertilizers. The FAO also reported that organic agriculture is likely to emit less nitrous oxide $\left(\mathrm{N}_{2} \mathrm{O}\right)$. According to the IOFOAM report the global adoption of organic agriculture would deliver additional emissions reductions of approximately. 0.6 to $0.7 \mathrm{Gt}$ $\mathrm{CO}_{2}$ eq through the avoidance of biomass burning $\left(\mathrm{CH}_{4}\right.$ and $\mathrm{N}_{2} \mathrm{O}$ emissions) and the avoidance of $0.41 \mathrm{Gt}$ $\mathrm{CO}_{2}$ eq/year emitted from the use of fossil energy consumption for chemical $\mathrm{N}$ fertilizer production. Inspite of all above merits organic farming have following limitations.

Yield is less during the initial period of conversion. High dependency on nutrients derived from livestock.

Non availability of organically treated seeds, availability of organic manures.

Less awareness about bio pesticides or non availability during disease attack.

Lack of complete package of practices.

Lack of technical knowledge.

Lack of genuine organic seed and planting material.

\section{SUGGESTIONS FOR STRENGTHEN OF ORGANIC FARMING IN INDIA}

For the large scale adaptation and promotion of organic farming among the farmers, following points need to be considered.

Development of basic infrastructures like soil testing laboratory, integrated pest management (IPM) and integrated nutrient management (INM) laboratories.

Development of organic research farm for carrying the various trials.

Establishment of bio-fertilizer production units.

Development of local manurial resources to generate sufficient organic manure.

Institutionalized capacity building programmes. 
Production of inputs locally by adopting different efficient technologies.

Establishment of supply chain mechanism and marketing federation for organic produce.

\section{Conclusion}

In the context of global warming and climate change, organic agriculture can be a potential strategy to mitigate consequences of climate change either by reducing $\mathrm{GHG}$ emissions or by sequestering $\mathrm{CO}_{2}$ from the atmosphere in the soil. Although the yield potential is little less in the initial period of conversion from conventional agriculture to organic agriculture but this can be managed by the reduction potential of the greenhouse gases emissions. Organic agriculture is potentially capable to serve the twin role of countries' food security and the environment protection. Even though the increasing trend in the organic agricultural area in the country, there is still need for further improvement, especially in the areas of research, extension and awareness among personnel directly or indirectly involved in the organic farming.

\section{REFERENCES}

Aggarawal, P. K. and Sinha, S. K. (1993). Effect of probable increase in carbon dioxide and temperature on wheat yields in India. Journal of Agricultural Meteorology, 48 (5): 811-814.

Aggarwal, P. K. (2003). Impact of climate change on Indian agriculture. Journal of Plant Biology, 30 (2): 189 - 198.

Aggarwal, P. K., Joshi, P. K., Ingram, J. S. I. and Gupta, R. K. (2004). Adapting food systems of the Indo-Gangetic plains to global environmental change: key information needs to improve policy formulation. Environment Science and Policy, 7: 487-498.

Aher, S. B., Sengupta, B. and Bhaveshanada, S. (2012). Organic agriculture: way towards sustainable development. ARPN Journal of Science and Technology, 2:318-324.

Bhattacharyya, P. and Chakraborty, G. (2005). Current status of organic farming in India and other countries. Indian Journal of Fertilizer, 1(9): 111-123.

CGWB (2009). Groundwater scenario of India 2009-10. Ministry of Water Resources Faridabad: 1-46.

Chakraborty, M. K. (1998). Principles and practice of organic farming. Kisan World, 45- 48.

Eyhorn, F., Ramakrishnan, R. and Mäder, P. (2007). The Viability of cotton-based organic farming systems in India. International of Journal Agricultural Sustainability, 5(1): 25-38.

FAO (2011). Organic agriculture and climate change mitigation. A report of the round table on organic agriculture and climate change. December 2011, Rome, Italy.

Foereid, B., Hastings, A. and Smith, P. (2008). Cool farming: Climate impacts of agriculture and mitigation potential (p. 28). Amsterdam: Greenpeace International.

Garg, A., Shukla, P. R., Bhattacharya, S. and Dadhwal, V. K. (2001). Sub-region (district) and sector level SO< sub $>$ $2</$ sub $>$ and $\mathrm{NO}<\mathrm{sub}>\mathrm{x}</$ sub $>$ emissions for India: assessment of inventories and mitigation flexibility. Atmospheric Environment, 35(4), 703-713.

Gattinger, A., Muller, A., Haeni, M., Skinner, C., Fliessbach, A., Buchmann, N., Mader, P., Stolze, M., Smith, P.,
Scialabba, N. E. and Niggli, U. (2012). Enhanced top soil carbon stocks under organic farming. Proceedings of the National Academy of Sciences, 109(44): 1822618231.

Goyal, R. K. (2004). Sensitivity of evapotranspiration to global warming: a case study of arid zone Rajasthan. Agricultural Water Management, 69 (1): 1-11.

IFOAM (2006). Mitigation and adaptation to climate change: The role of organic agriculture. IFOAM side event to the $24^{\text {th }}$ session of the subsidiary bodies, Bonn, Germany, May 24, 2006.

IFOAM (2009). High sequestration low emission food secures farming. Organic agriculture a guide to climate change and food security. http://orgprints.org/16769/1/ IFOAM-CC-Guide-Web-20100210.pdf

IFOAM (2012). The world of organic agriculture. Statistics and emerging trends 2012. International federation of organic agriculture movements (IFOAM), Bonn and Research Institute of Organic Agriculture FiBL, Frick, $27-35$.

INCCA (2010). Indian Network for Climate Change Assessment, Climate Change and India: A 4x4 Assessment, Ministry of Environment and Forests, Government of India, 2010.

IPCC (2001). Climate change: the scientific basis. Intergovernmental panel on climate change. Cambridge (UK): Cambridge Univ. Press.

IPCC (2007a). Climate Change 2007: The Physical Science Basis. Contribution of working group I to the fourth assessment report of the Intergovernmental Panel on Climate Change. Cambridge University Press, Cambridge, United Kingdom and New York, NY, USA.

IPCC (2007b). Climate Change 2007: Impacts, Adaptation and Vulnerability. Working group II contribution to the fourth assessment report. Cambridge Univ. Press, Cambridge, UK, 2007.

Jorden, R., Muller, A. and Oudes, A. (2009). High carbon sequestration, low emission food secure farming. Organic Agriculture- a guide to climate change and Food Security.

Khan, S. A., Kumar, S., Hussain, M. Z. and Kalra, N. (2009). Climate change, climate variability and Indian agriculture: Impacts vulnerability and adaptation strategies. In Climate Change and Crops. Springer Berlin Heidelberg.

Krishna Kumar, K., Patwardhan, S. K., Kulkarni, A., Kamala, K., KoteswaraRao, K. and Jones, R. (2011). Simulated projections for summer monsoon climate over India by a high-resolution regional climate model (PRECIS). Current Science, 101(3): 312-26.

Kumar, K. K., Kumar, K. R., Ashrit, R. G., Deshpande, N. R. and Hansen, J. W. (2004). Climate impacts on Indian agriculture. International Journal of Climatology, 24 (11): 1375-93.

Kumar, K. S. and Parikh, J. (2001). Indian agriculture and climate sensitivity. Global Environment Change, 11 (2):147-54.

Lal, R. (2004a). Carbon emission from farm operations. Environment International, 30: 981-90.

Lal, R. (2004b). Soil carbon sequestration to mitigate climate change. Geoderma, 123:1-22.

Lampkin, N. (2007). Organic farming's contribution to climate change and agricultural sustainability. Welsh organic producer conference, $18^{\text {th }}$ October 2007.

Maity, T. K., and Tripathy, P. (2004). Organic Farming of 
Vegetables in India: Problems and Prospects. $w w w$. share 4dev. info/kb/documents/2997. Pdf

Mall, R. K., Singh, R., Gupta, A., Srinivasan, G. and Rathore, L. S. (2006). Impact of climate change on Indian agriculture: A review. Climatic Change, 78 (24): 445-78.

Meredith, N. (2008). Sustainable soils: reducing, mitigating, and adapting to climate change with organic agriculture. Sustainable Development Law \& Policy, 19 -23: 68-69.

Mimi, Z. A., and Jamous, S. A. (2010). Climate change and agricultural water demand: Impacts and adaptations. African Journal of Environmental Science and Technology, 4(4): 183-91.

MOA (2012). State of Indian Agriculture 2012-13. Ministry of Agriculture, GOI, Department of agriculture and co operation, Directorate of Statistics and economics, New Delhi.

Muller (2009). Benefits of organic agriculture as a climate change adaptation and mitigation strategy for developing countries. Environment for development Discussion Paper Series

Muller, A., Olesen, J., Davis, J., Smith, L., Dytrtová, K., Gattinger, A., Lamp-kin, N. and Niggli, U. (2012). Reducing global warming and adapting to climate change: The potential of organic agriculture. Working paper, draft version, 2012, FiBL Schweiz / Suisse, info.suisse@fibl.org, www.fibl.org.

Olesen, J. E., Schelde, K., Weiske, A., Weisbjerg, M. R., Asman, W. A. H. and Djurhuus, J. (2006). Modelling greenhouse gas emissions from European conventional and organic dairy farms. Agriculture, Ecosystems \& Environment, 112: 207-222.

Pandey, J. and Singh, A. (2012). Opportunities and constraints in organic farming: an Indian perspective. Journal of Scientific Research, 56: 47-72.

Panwar, R. P., Singh, N. R., Ramana, A. B., Yadav, S., Shrivastava, S. K. and SubbaRao, R. (2010). Status of organic farming in India. Current Science, 98: 1090 -1194.

Patle, G. T., Bandyopadhyay, K. K. and Singh, D. K. (2013b). Impact of conservation agriculture and resource conservation technologies on carbon sequestration - a review. Indian Journal of Agricultural Sciences, 83 (1): 3-13.

Patle, G. T., Singh, D. K., Sarangi, A., Rai, A., Khanna, M. and Sahoo, R. N. (2013a). Temporal variability of climatic parameters and potential evapotranspiration. Indian Journal of Agricultural Sciences, 83 (4): 518-24.
Pimentel, D., Hepperly, P., Hanson, J., Douds, D. and Seidel, R. (2005). Environmental, energetic, and economic comparisons of organic and conventional farming systems. BioScience, 55(7): 573-582.

Pretty, J. and Ball, A. (2001). Agricultural influences on carbon emissions and sequestration: a review of evidence and the emerging trading options. Centre for Environment and Society Occasional Paper, 3.

Rao, D. G., and Sinha, S. K. (1994). Impact of climate change on simulated wheat production in India. Implications of Climate Change for international agriculture: Crop Modelling Study, 2(3), 4-0.

Schader, C., Stolze, M. and Gattinger, A. (2011). Environmental performance of organic agriculture' in Boye, J. and Arcand, Y. (eds.), Green Technologies in Food Production and Processing, New York, Springer.

Sharma, A. K. (2001). A Handbook of Organic Farming, Agrobios, Jodhpur, India, 2001.

Sinha, S. K. and Swaminathan, M. S. (1991). Deforestation, climate change and sustainable nutrition security: a case study of India. Climatic Change, 19 (1-2): 201-209.

Sinha, S. K., Singh, G. B. and Rai, M. (1998). Decline in crop productivity in Haryana and Punjab: Myth or reality. Indian Council of Agricultural Research, New Delhi, India, 89

Verge, X. P. C., Kimpe, C. D. and Desjardins, R. L. (2007). Agricultural production, greenhouse gas emissions and mitigation potential. Agricultural and Forest Meteorology, 142: 255-69.

Wani, S. A., Chand, S., Najar, G. R. and Teli, M. A. (2013). Organic farming: As a climate change adaptation and mitigation strategy. Current Agriculture Research Journal, 1(1): 45-50.

West, T. O. and Marland, G. (2002). A synthesis of carbon sequestration, carbon emissions, and net carbon flux in agriculture: comparing tillage practices in the United States. Journal of Agriculture Ecosystems and Environment, 91:217-232.

Yadav, A. K. (2012). Status of organic agriculture in India 2010-11. Organic farming Newsletter, 8(2): 11-14.

Indiastat (2013). Area under organic farming in India. http:// www.indiastat.com/agriculture/2/agriculturalarealandus e /152/stats.aspx. Assessed on 03.10.2013.

Ziesemer, J. (2007). Energy use in organic food systems. Natural Resources Management and Environment Department Food and Agriculture Organization of the United Nations, Rome. 